\title{
British Dental Association Annual General Meeting
}

The Annual General Meeting of the British Dental Association will be held at 9.45am on Thursday 19 May 2011 in the Exchange Auditorium, Manchester Central Convention Complex. Notice of the meeting and the business to be transacted was given by order of the Executive Board in the British Dental Journal edition of 23 April 2011

\section{WELCOME}

Welcome and introduction from the Chair of the Representative Body, Stuart Johnston

\section{REPORTS}

Oral report from the Chief Executive, Peter Ward

\section{ORDINARY BUSINESS}

To receive and consider the audited accounts for the financial year ended 30 September 2010 and the report of the directors and of the auditors, as included in the 23 April 2011 edition of the British Dental Journal

To reappoint BDO LLP, chartered accountants, as auditors and to authorise the Executive Board to fix their remuneration

To consider and, if thought fit, to pass the following resolutions recommended to the meeting by the Representative Body:

- that Frank Holloway be elected President for 2012 - 2013

- that the 2012 Annual General Meeting be held at 9.45am on Thursday 26 April 2012 at the Manchester Central Convention Complex

\section{ANY OTHER BUSINESS}

